\title{
ОСОБЛИВОСТІ МОРФОЛОГІЧНИХ ЗМІН У КІСТКОВІЙ ТКАНИНІ ПРИ ЗАСТОСУВАННІ МАТЕРІАЛУ НА ОСНОВІ ГІДРОКСИАПАТИТУ ТА ПОЛІЛАКТИДУ
}

\begin{abstract}
Резюме. Остеорегенерація при відновленні кісткових дефектів щелеп є важливим питанням сучасної стоматології. Незважаючи на численні опубліковані праці, ідеального матеріалу все ще не існує, а тому його пошук $є$ актуальним.

Мета дослідження - вивчити процеси остеорегенерації шляхом морфометричного оцінювання мікропрепаратів та проведення порівняльного аналізу репарації у кореляції із макроскопічними даними на 180 добу експерименту.

Матеріали і методи. Експеримент проведено на білих щурах-самцях масою 180-200 г. Під загальним знеболюванням тваринам створювали наскрізний отвір у ділянці щелепи. У контрольній групі загоєння відбувалось лише під кров'яним згортком, а у дослідних групах кістковий десрект заміщувався матеріалом на основі гідроксиапатиту та полілактиду з різним відсотковим умістом компонентів (перша група (80 \%/20 \%) та друга група (50 \%/50 \%)). Морфометричну оцінку здійснювали за допомогою вставок окуляра-мікрометра з вимірювальними сітками для цитогістостереометричних досліджень. При макроскопічному обстеженні візуально оцінювали загальний вигляд вилучених щелеп та прилеглих тканин.

Результати досліджень та їх обговорення. Значні за своїм об'ємом десекти нижньої щелепи мають тенденцію до спотвореної та замісної регенерації із виповненям практично усього об'єму немінералізованою тканиною, близькою за своєю будовою до органічного матриксу кістки. Остеоімплантат із співвідношенням полілактиду та синтетичного гіпроксиапатиту 20/80 сприяє меншій деструкції тканин, структурно правильній організації органічного матриксу кістки та швидшій його мінералізації з формуванням первинної кісткової мозолі на 30 добу. На 180 добу процеси перебудови та транссормації рубця у зрілу кісткову тканину відбуваються ще досить інтенсивно. При застосуванні імплантата у складовій пропорції 50/50 регенерація має більш сприятливий перебіг, про що свідчить практичне відновлення структури кістки на 180 добу спостереження, коли основну частину регенерату (70 \%) у десекті представлено зрілою пластинчастою кісткою. Дані, отримані при оцінці макропрепаратів нижніх щелеп тварин, корелювали з даними морфометричного дослідження.

Висновки. Заповнення кісткових десектів запропонованими остеоімплантатами змінює перебіг регенерації. Встановлено, що виповнення десеекту резорбуючим композитом зменшує деструктивні процеси та пришвидшує фрормування первинної та вторинної кісткової мозолі. У цьому відношенні більш ефеектвною виявилась композиція з одинаковим вмістом обох ії складових.
\end{abstract}

Ключові слова: кістковий дефект; регенерація кісткової тканини; гідроксиапатит; полілактид.

встУп Тривале вивчення процесів регенерації кісткової тканини [1-3] на сьогодні все ще не усуває проблеми вибору матеріалу. В клінічній практиці застосовують велику кількість різноманітних остеопластичних середників біологічного і синтетичного походжень, проте жоден із них не набув широкого застосування [4-9]. Зважаючи за значний ріст різноманітних контагіозних інфрекційних захворювань, які здатні передаватися між організмами не залежно від їх виду, та враховуючи також певні біоетичні питання, найбільшого поширення набули пластичні матеріали синтетичного походження. Їх основу складають синтетичні аналоги мінеральної складової кісток, зокрема гідроксиапатит та схожі до нього сполуки.

Оскільки вказані мінеральні сполуки синтезуються у виді сипучої речовини - порошку, для зручності використання та надання певної форми до них додають різного роду скріплювальні речовини, однією з яких є резорбуючий біополімер молочної кислоти - полілактид, який вже не один рік широко використовують у медичній практиці (найпоширеніший приклад - шовний хірургічний матеріал) [10]. Завдяки цьому можна фрормувати імплантаційний матеріал у вигляді гранул або суцільних блоків необхідної величини та форми [11].

Хоча у науковій літературі є згадки та дані дослідження такого роду композиції як оптимізатора кісткової регенерації [12-14], проте у жодних із них не досліджувались відмінності впливу відсотково різноскладових варіантів композиції на процеси остеорегенерації та не фрормувалися на основі таких досліджень практичні рекомендації до їх застосування.

Метою дослідження було вивчення процесів остеорегенерації шляхом оцінювання морфометричних даних як у контрольній групі (загоєння під кров'яним згортком), так і в дослідних групах, де кістковий десрект заміщувався остеопластичним матеріалом на основі гідроксиапатиту та полілактиду з різним відсотковим вмістом компонентів та проведення макроскопічного порівняльного аналізу репарації на 180 добу експерименту.

МАТЕРІАЛИ І МЕТОДИ Експеримент проведено на білих статевозрілих щурах-самцях масою 180-200 г, яких утримували на стандартному раціоні віварію. Тварин поділили на групи: контрольну та першу і другу дослідні. Кожну групу поділили на підгрупи, залежно від термінів вилучення тварин з експерименту (по 6 тварин на термін). Усі маніпуляції із піддослідними тваринами здійснювали відповідно до міжнародних вимог згідно з Європейською конвенцією про захист хребетних тварин, що використовуються для дослідних та інших наукових цілей (Страсбург, 1986) та Загальних етичних принципів експериментів на тваринах, ухвалених Першим національним конгресом із біоетики (Київ, 2001). Оперативне втручання проводили під загальним знеболюванням. Для цього використовували 0,04 мл 5 \% розчину тіопенталу натрію. Оперували тварин за загальновідомою методикою (А. Д. Чечин, 1989), дещо її модифрікувавши. Після видалення шерстяного покрову (проекція нижньої щелепи та підщелепна ділянка зліва) та обробки операційного поля 3 \% розчином йоду, проводили розріз шкіри паралельно та нижче від нижнього краю нижньої щелепи довжиною 1-1,5 см. Далі тупим шляхом відсепаровували м'які тканини до кістки. За допомогою фрізіодиспенсера SURGEC XT (NSK, Японія) при швидкості 800 об./хв із постійним охолодженням 0,9\% розчином хлориду натрію створювали наскрізний отвір у ділянці кута нижньої щелепи зліва. Діаметр стоматологічного бора - 2 мм. У контрольній серії дослідів після антисептичної обробки 
рану зашивали. Шви на шкірі зволожували 1\% розчином брильянтового зеленого. У першій дослідній групі використовували імплантаційний матеріал (гідроксиапатит 80 \% плюс полілактид 20 \%), в другій дослідній групі використовували імплантаційний матеріал (гідроксиапатит 50 \% + полілактид 50 \%). Для створення цієї композиції використовували полілактид (Poly (L-Lactide) Purasorb PL 32 (Holland) та гідроксиапатит (ГА) $\mathrm{Ca}_{10-x}\left(\mathrm{PO}_{4}\right)_{6}(\mathrm{OH})_{2} 3$ розміром частинок 0,1 мм (температура спікання $=1050^{\circ} \mathrm{C}$ ), синтезований на кафедрі хімічної технології силікатів НУ "Львівська політехніка". Блокову (ко)полімеризацію композицій здійснювали у термошафрі на повітрі за температури 348 К протягом 4,5 год. Після закінчення синтезу полімерні зразки охолоджували до кімнатної температури 1,5-2 год. Виводили тварин 3 експерименту на 7; 14; $21 ; 30 ; 90 ; 180$ доби шляхом передозування розчину тіопенталу натрію, який вводили внутрішньочеревно.

Для гістологічного дослідження отриманий біопсійний матеріал - нижні щелепи щурів - фріксували в 10 \% розчині нейтрального фрормаліну з наступною декальцинацією в $10 \%$ розчині азотної кислоти впродовж 7-10 днів. Декальциновані зразки зневоднювали в спиртах зростаючої концентрації та заливали в парафрін. Виготовлення серійних гістологічних зрізів товщиною 7-10 мкм із парафрінових блоків проводили на санному мікротомі. Гістологічні зрізи фрарбували гематоксиліном та еозином. Огляд і опис отриманих гістологічних препаратів проводили під різними збільшеннями об'єктива та окуляра. Як критерії оцінки, використовували такі характеристики темпи утворення клітинно-волокнистої остеогенної тканини, терміни появи й об'єми остеоїдних і фріброзних кісткових структур, їх відношення до м'яко-тканинного компоненту в різні терміни експерименту, швидкість дозрівання і дисеренціації структур новоутвореної кістки, у тому числі фрормування кортикальної пластини. Морфометричну оцінку здійснювали за допомогою вставок окуляра-мікрометра з вимірювальними сітками для цитогістостереометричних досліджень. Згідно з принципом M. Delesse [16], частка площі зрізу, що містить досліджуваний компонент, рівна його частці в об'ємі досліджуваного об'єкта. Якщо на площу спостереження, яка містить декілька об'єктів, накласти систему точок, то відношення кількості точок, які потрапили на об'єкти до загального числа точок, рівне питомій площі об'єктів. Розрахунки проводили за наступною формулою:

$$
\mathrm{S}_{\mathrm{A}}=\rho / \mathrm{P},
$$

де $\mathrm{S}_{\mathrm{A}}$ - питома площа об'єкта;

$\rho$ - кількість точок, які потрапили на об'єкти;

Р - загальна кількість точок.

Об'єктом морфометрії були складові компоненти регенерату, відсоткові відношення яких підраховувалися на одиницю площі регенерату в трьох зрізах кожного блоку. Такою одиницею площі регенерату був великий квадрат окулярної стереологічної сітки, що містить 100 вузлових точок, що приймалися за 100 \% площі регенерату. За кількістю точок окулярної сітки, здійснювали вимірюванням частки об'ємних відношень імплантата, сполучної і кісткової тканин у складі кісткового регенерату. Це дозволило відсотково представити динаміку в перебудові біоімплантата та тканин дефекту.

При макроскопічному обстеженні оцінювали загальний вигляд вилучених щелеп та прилеглих тканин. Звертали увагу на наявність чи відсутність запальної реакції у кожному макропрепараті. В препаратах дослідних груп відмічали наявність імплантаційного матеріалу, ступінь його резорбції залежно від термінів виведення тварини з експерименту. Візуально, оцінюючи величину дефекту, відмічали регенеративну здатність кісткової тканини.

РЕЗУЛЬТАТИ ДОСЛІДЖЕНЬ ТА ЇХ ОБГОВОРЕННЯ Отримані дані морфометричного дослідження мікропрепаратів тварин контрольної групи подано у таблиці 1.

У регенераті експериментально створених десректів нижньої щелепи, в ранніх термінах в основному виявлено кров'яний згусток та тканинний дентрит. На 7 добу він складав $(76,0 \pm 1,2)$ \% від усього об'єму, що виповнював кістковий десект. Поступово його кількість зменшувалася до $(61,0 \pm 1,1) \%$ на 14 добу та $(11,0 \pm 0,7) \%$ - на 21 добу. В наступних термінах дослідження тканинного дентриту не було виявлялено. Пухка сполучна тканина була на 7 добу спостереження, коли на їі частку припадало $(24,0 \pm 1,2) \%$ усього складу регенерату. Поступово її відсоток зростав до $(39,0 \pm 1,1) \%$ на 14 добу і до $(84,0 \pm 1,1) \%$ - на 21 добу. Надалі їі кількість різко зменшувалася до $(31,7 \pm 1,1) \%$ на 30 добу. Пухку сполучну тканину можна було ще виявити на 90 добу дослідження, коли її частка складала $(11,7 \pm 1,1) \%$ від усього об'єму регенерату.

Остеоїдна сполучна тканина у регерераті тварин контрольної групи починала з'являтися на 21 добу, а її частка на цей момент у середньому складала $(5,0 \pm 0,4)$ \%. У наступному терміні (30 доба) виявлено різке ії відсоткове зростання до $(58,2 \pm 1,3) \%$. Ще більшу частку в усьому регенераті остеоїдна тканина займала на 90 добу $(74,3 \pm 1,5) \%$. На завершення спостереження її відсоткова доля у регенераті дещо зменшилася та складала $(66,5 \pm 1,3) \%$.

Хрящова тканина виявлялася в остеорегенератах тварин контрольної групи на 30 добу із значенням у $(8,0 \pm 0,4) \%$. Поступово ії̈ кількість зростала до $(12,2 \pm 0,2)$ $\%$ на 90 добу та $(25,0 \pm 0,7) \%$ на завершення спостереження (180 доба).

Частка грубоволокнистої кісткової тканини, що з'являлася лише у крайових ділянках дефекту на 30 добу, склала $(2,0 \pm 0,5) \%$, незначно зростала, до $(2,2 \pm 0,3) \%$ на 90 добу, а на 180 добу досягала $(8,2 \pm 0,4) \%$.

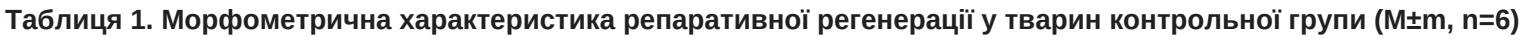

\begin{tabular}{|c|c|c|c|c|c|c|c|}
\hline \multirow{2}{*}{$\begin{array}{l}\text { Термін } \\
\text { (доба) }\end{array}$} & \multicolumn{7}{|c|}{ Склад регенерату (\%) } \\
\hline & $\begin{array}{c}\text { біополімерний } \\
\text { імплантат }\end{array}$ & $\begin{array}{c}\text { згустки крові, } \\
\text { тканинний детрит }\end{array}$ & $\begin{array}{c}\text { пухка сполучна } \\
\text { тканина }\end{array}$ & \begin{tabular}{|c|} 
остеоїдна \\
сполучна тканина
\end{tabular} & $\begin{array}{l}\text { хрящева } \\
\text { тканина }\end{array}$ & $\begin{array}{l}\text { грубоволокниста } \\
\text { кісткова тканина }\end{array}$ & \begin{tabular}{|c|} 
пластинчаста \\
кісткова тканина
\end{tabular} \\
\hline 7 & - & $76,0 \pm 1,2$ & $24,0 \pm 1,2$ & - & - & - & - \\
\hline 14 & - & $61,0 \pm 1,1$ & $39,0 \pm 1,1$ & - & - & - & - \\
\hline 21 & - & $11,0 \pm 0,7$ & $84,0 \pm 1,1$ & $5,0 \pm 0,4$ & - & - & - \\
\hline 30 & - & - & $31,7 \pm 1,1$ & $58,2 \pm 1,3$ & $8,0 \pm 0,4$ & $2,0 \pm 0,5$ & - \\
\hline 90 & - & - & $11,7 \pm 1,1$ & $74,3 \pm 1,5$ & $12,2 \pm 0,2$ & $2,2 \pm 0,3$ & - \\
\hline 180 & - & - & - & $66,5 \pm 1,3$ & $25,0 \pm 0,7$ & $8,2 \pm 0,4$ & $0,5 \pm 0,2$ \\
\hline
\end{tabular}


Зрілу пластинчасту кісткову тканину можна було виявити лише на межі неушкодженої кісткової тканини та дефекту лише на 180 добу, а її відсоток був вкрай незначним $(0,5 \pm 0,2) \%$.

Одним із найважливіших показників, що визначає есрективність застосування будь-якого кісткового замінника, є ступінь його біодеградації, або швидкість розсмоктуваня, яка в ідеалі повинна бути повністю збалансованою до біохімічних та морфологічних процесів, що відбуваються в ділянці дефекту та навколишніх його тканинах. Дані щодо складу остеорегенрату в тварин першої дослідної групи представлено у таблиці 2.

Як бачимо, у тварин першої дослідної групи вже на 7 добу експерименту відбулося часткове розсмоктування остеоімплантата з практично повним його заповненням десректу до $(85,0 \pm 1,1) \%$. У всіх наступних термінах його частка також рівномірно та поступово продовжувала зменшуватися, та складала $(77,0 \pm 1,1) \%$ на 14 добу, $(66,0 \pm 1,3) \%$ - на 21 добу, $(55,0 \pm 1,3) \%$ - на 30 добу, $(23,5 \pm 1,3) \%$ - на 90 добу. Навіть у останньому терміні дослідження ще зберігався значний його відсоток у складі регенерату, на який припадало до $(12,7 \pm 0,9) \%$.

Зважаючи на практично повне заповнення остеоімплантом змодельованого десекту тіла нижньої щелепи, відсоток, який припадає на кров'яний згусток та зруйновані тканини, був незначним (не більше $(1,0 \pm 0,4) \%)$ та спостерігався лише впродовж 7 діб.

Але замість нього була у дефекті пухка сполучна тканина, яка на 7 добу складала $(14,0 \pm 0,7)$ \% складу регенерату та мала тенденцію до свого зростання до $(15,5 \pm 1,7) \%$ на 14 добу та $(18,0 \pm 1,3) \%$ - на 21 добу. Надалі процес остеорегенерації характеризувався зменшенням їі частки до $(7,0 \pm 0,4) \%$ та розміщенням в основному навколо ще не розсмоктаного біоматеріалу та повною відсутністю на 90 та 180 доби.

Остеоїдна тканина у значній кількості з'являється у регенераті тварин першої дослідної групи на 14 добу $(6,0 \pm 0,9) \%$, характеризується поступовим зростанням до $(11,0 \pm 0,9) \%$ на 21 добу, $(24,0 \pm 1,1) \%$ - на 30 добу. В досить значній кількості, що свідчить про очевидну перебудову регенерату, визначається на 90 та 180 доби (відповідно $(41,5 \pm 0,9) \%$ та $(12,5 \pm 2,1) \%))$.

При застосуванні запропонованого остеорегенерту в пропорції 20/80 вдається уникнути фрази ендохондрального остеогенезу, так як хрящова тканина практично не визначається в регенераті на будь-якому терміні спостереження.

Незріла грубоволокниста кісткова тканина починала визначатися у регенераті тварин першої дослідної групи вже на 14 добу $(1,5 \pm 0,2) \%$, а її вміст у всіх наступних термінах зростав до $(5,0 \pm 0,9) \%$ на 21 добу та $(9,0 \pm 1,3)$ $\%$ - на 30 добу. Необхідно відмітити, що досить значну кількість незрілої кісткової тканини можна було ще визначити на 90 та 180 доби, відповідно $(19,7 \pm 2,0) \%$ та $(26,5 \pm 0,7) \%$.

Зріла пластинчаста кісткова тканина у значній кількості починала спостерігатися на 30 добу дослідження, поступово зростала до $(15,3 \pm 0,9) \%$ на 90 добу. Проте навіть на 180 добу її кількість становила $(51,7 \pm 3,1) \%$, що ще не відповідає показникам фрізіологічної норми.

Отримані дані аналогічного дослідження кісткових регенератів у десректах нижньої щелепи тварин другої дослідної групи представлено у таблиці 3.

Ступінь біодеградації імпланта 3 пропорційним відношенням компонентів 50/50 була більшою. На 7 добу вміст біоостеоімплантата, безпосередньо в ділянці дефректу, складав $(73,2 \pm 1,1) \%$. Унаслідок розсмоктування його частка на 14 добу зменшувалася до $(59,7 \pm 0,9) \%$, на 21 добу - до $(44,0 \pm 1,3) \%$, на 30 добу - $(32,0 \pm 1,3) \%$, на 90 добу - $(18,0 \pm 1,0) \%$, а на 180 добу він практично був повністю розсмоктаним із залишком лише у $(3,0 \pm 0,4) \%$.

Відповідно до умов експерименту, внаслідок практично повного виповнення експериментального дефекту кістки імплантаційним матеріалом, згустків крові та зруйнованих тканин у досліджуваній ділянці була мінімальна кількість (до $(1,0 \pm 0,4) \%$ на 7 добу).

У початкових термінах дослідження більша частина десекту, не заповнена остеоімплантатом, заміщена пухкою сполучною тканинною, частка якої на 7 добу становила до $(26,0 \pm 0,7) \%$. Поступово у більш віддалені терміни її відсоткова складова зменшується до $(22,3 \pm 1,5)$ $\%$ на 14 добу, $(23,0 \pm 1,3) \%$ - на 21 добу, $(3,5 \pm 0,25) \%$ - на 30 добу. На 90 та 180 доби їі у регенераті не спостерігалося.

Немінералізована кісткова (остеоїдна) тканина починає інтенсивно визначатися у кістковому регенераті тварин другої дослідної групи на 14 добу $(12,0 \pm 1,3) \%$, зростає на 21 та 30 доби - до $(18,3 \pm 1,3) \%$ та $(33,5 \pm 1,9)$ \% відповідно. Також її можна спостерігати на завершальних термінах - на 90 та 180 доби ії складова частка до-

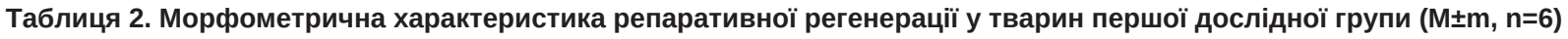

\begin{tabular}{|c|c|c|c|c|c|c|c|}
\hline \multirow{2}{*}{$\begin{array}{l}\text { Термін } \\
\text { (доба) }\end{array}$} & \multicolumn{7}{|c|}{ Склад регенерату (\%) } \\
\hline & $\begin{array}{c}\text { біополімерний } \\
\text { імплантат }\end{array}$ & $\begin{array}{c}\text { згустки крові, } \\
\text { тканинний детрит }\end{array}$ & $\begin{array}{c}\text { пухка сполучна } \\
\text { тканина }\end{array}$ & \begin{tabular}{|c|} 
остеоїдна \\
сполучна тканина
\end{tabular} & \begin{tabular}{|l} 
хрящева \\
тканина
\end{tabular} & $\begin{array}{l}\text { грубоволокниста } \\
\text { кісткова тканина }\end{array}$ & $\begin{array}{c}\text { пластинчаста } \\
\text { кісткова тканина }\end{array}$ \\
\hline 7 & $\begin{array}{c}85,0 \pm 1,1 \\
p<0,05\end{array}$ & $\begin{array}{l}1,0 \pm 0,4 \\
p<0,05\end{array}$ & $\begin{array}{c}14,0 \pm 0,7 \\
p<0,05\end{array}$ & - & - & - & - \\
\hline 14 & $\begin{array}{l}77,0 \pm 1,1 \\
p<0,05\end{array}$ & - & $\begin{array}{c}15,5 \pm 1,7 \\
p<0,05\end{array}$ & $\begin{array}{l}6,0 \pm 0,9 \\
p<0,05\end{array}$ & - & $\begin{array}{l}1,5 \pm 0,2 \\
p<0,05\end{array}$ & - \\
\hline 21 & $\begin{array}{c}66,0 \pm 1,3 \\
p<0,05\end{array}$ & - & $\begin{array}{c}18,0 \pm 1,3 \\
p<0,05\end{array}$ & $\begin{array}{l}11,0 \pm 0,9 \\
p<0,05\end{array}$ & - & $\begin{array}{l}5,0 \pm 0,9 \\
p<0,05\end{array}$ & - \\
\hline 30 & $\begin{array}{c}55,0 \pm 1,3 \\
p<0,05\end{array}$ & - & $\begin{array}{l}7,0 \pm 0,4 \\
p<0,05\end{array}$ & $\begin{array}{c}24,0 \pm 1,1 \\
p<0,05\end{array}$ & - & $\begin{array}{l}9,0 \pm 1,3 \\
p<0,05\end{array}$ & $\begin{array}{l}5,0 \pm 0,7 \\
p<0,05\end{array}$ \\
\hline 90 & $\begin{array}{c}23,5 \pm 1,6 \\
p<0,05\end{array}$ & - & - & $\begin{array}{l}41,5 \pm 0,9 \\
p<0,05\end{array}$ & - & $\begin{array}{c}19,7 \pm 2,0 \\
p<0,05\end{array}$ & $\begin{array}{l}15,3 \pm 0,9 \\
p<0,05\end{array}$ \\
\hline 180 & $\begin{array}{l}12,7 \pm 0,9 \\
p<0,05\end{array}$ & - & - & $\begin{array}{c}12,5 \pm 2,1 \\
p<0,05\end{array}$ & - & $\begin{array}{c}26,5 \pm 0,7 \\
p<0,05\end{array}$ & $\begin{array}{l}51,7 \pm 3,1 \\
p<0,05\end{array}$ \\
\hline
\end{tabular}

Примітка. р - значення коесріцієнта достовірності до контрольної групи тварин. 
ISSN 1681-276Х. ВІСНИК НАУКОВИХ ДОСЛІДЖЕНЬ. 2017. № 3

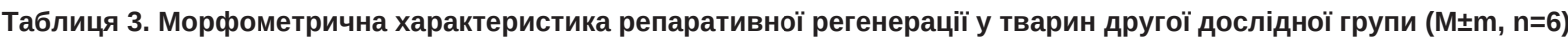

\begin{tabular}{|c|c|c|c|c|c|c|c|}
\hline \multirow{2}{*}{$\begin{array}{l}\text { Термін } \\
\text { (доба) }\end{array}$} & \multicolumn{7}{|c|}{ Склад регенерату (\%) } \\
\hline & $\begin{array}{c}\text { біополімерний } \\
\text { імплантат }\end{array}$ & $\begin{array}{c}\text { згустки крові, } \\
\text { тканинний детрит }\end{array}$ & $\begin{array}{c}\text { пухка сполучна } \\
\text { тканина } \\
\end{array}$ & $\begin{array}{c}\text { остеоїдна } \\
\text { сполучна тканина }\end{array}$ & $\begin{array}{c}\text { хрящева } \\
\text { тканина }\end{array}$ & $\begin{array}{l}\text { грубоволокниста } \\
\text { кісткова тканина }\end{array}$ & $\begin{array}{c}\text { пластинчаста } \\
\text { кісткова тканина }\end{array}$ \\
\hline 7 & $\begin{array}{l}73,2 \pm 1,1 \\
p_{1}<0,05 \\
p_{2}<0,05\end{array}$ & $\begin{array}{l}1,0 \pm 0,4 \\
p_{1}<0,05 \\
p_{2}>0,05\end{array}$ & $\begin{array}{c}26,0 \pm 0,7 \\
p_{1}>0,05 \\
p_{2}<0,05\end{array}$ & - & - & - & - \\
\hline 14 & $\begin{array}{l}59,7 \pm 0,9 \\
p_{1}<0,05 \\
p_{2}<0,05\end{array}$ & - & $\begin{array}{l}22,3 \pm 1,5 \\
p_{1}<0,05 \\
p_{2}<0,05\end{array}$ & $\begin{array}{l}12,0 \pm 1,3 \\
p_{1}<0,05 \\
p_{2}<0,05\end{array}$ & - & $\begin{array}{l}6,0 \pm 0,7 \\
p_{1}<0,05 \\
p_{2}<0,05\end{array}$ & - \\
\hline 21 & $\begin{array}{l}44,0 \pm 1,3 \\
\mathrm{p}_{1}<0,05 \\
\mathrm{p}_{2}<0,05 \\
\end{array}$ & - & $\begin{array}{l}23,0 \pm 1,3 \\
\mathrm{p}_{1}<0,05 \\
\mathrm{p}_{2}<0,05\end{array}$ & $\begin{array}{l}18,3 \pm 1,3 \\
\mathrm{p}_{1}<0,05 \\
\mathrm{p}_{2}<0,05\end{array}$ & - & $\begin{array}{l}10,5 \pm 1,6 \\
\mathrm{p}_{1}<0,05 \\
\mathrm{p}_{2}<0,05\end{array}$ & $\begin{array}{l}5,0 \pm 0,9 \\
\mathrm{p}_{1}<0,05 \\
\mathrm{p}_{2}<0,05\end{array}$ \\
\hline 30 & $\begin{array}{l}32,0 \pm 1,3 \\
\mathrm{p}_{1}<0,05 \\
\mathrm{p}_{2}<0,05\end{array}$ & - & $\begin{array}{l}3,5 \pm 0,2 \\
p_{1}<0,05 \\
p_{2}<0,05\end{array}$ & $\begin{array}{l}33,5 \pm 1,9 \\
\mathrm{p}_{1}<0,05 \\
\mathrm{p}_{2}<0,05\end{array}$ & - & $\begin{array}{l}17,0 \pm 1,1 \\
\mathrm{p}_{1}<0,05 \\
\mathrm{p}_{2}<0,05\end{array}$ & $\begin{array}{l}14,0 \pm 0,7 \\
\mathrm{p}_{1}<0,05 \\
\mathrm{p}_{2}<0,05\end{array}$ \\
\hline 90 & $\begin{array}{l}18,0 \pm 1,0 \\
\mathrm{p}_{1}<0,05 \\
\mathrm{p}_{2}<0,05 \\
\end{array}$ & - & - & $\begin{array}{l}14,0 \pm 0,4 \\
\mathrm{p}_{1}<0,05 \\
\mathrm{p}_{2}<0,05\end{array}$ & - & $\begin{array}{l}16,3 \pm 2,6 \\
\mathrm{p}_{1}<0,05 \\
\mathrm{p}_{2}>0,05 \\
\end{array}$ & $\begin{array}{l}51,7 \pm 3,1 \\
\mathrm{p}_{1}<0,05 \\
\mathrm{p}_{2}<0,05 \\
\end{array}$ \\
\hline 180 & $\begin{array}{l}3,0 \pm 0,4 \\
p_{1}<0,05 \\
p_{2}<0,05 \\
\end{array}$ & - & - & $\begin{array}{l}11,7 \pm 0,6 \\
p_{1}<0,05 \\
p_{2}>0,05\end{array}$ & - & $\begin{array}{l}13,3 \pm 2,5 \\
p_{1}<0,05 \\
p_{2}<0,05\end{array}$ & $\begin{array}{l}70,0 \pm 2,6 \\
p_{1}<0,05 \\
p_{2}<0,05\end{array}$ \\
\hline
\end{tabular}

Примітки: 1) р

2) $p_{2}$ - значення коесріцієнта достовірності до першої дослідної групи.

рівнювала $(14,0 \pm 0,4) \%$ та $(11,7 \pm 0,6) \%$, яка розміщувалася в основному навколо ще нерозмоктаного біоматеріалу.

Позитивною стороною застосування біоостеоімплантата у пропорційному відношенні 50/50 можна вважати відсутність хрящової тканини у складі регенерату, яка не визначається у жодному терміні дослідження.

Мінералізована незріла кісткова тканина з'являється в регенераті на 14 добу, де ії відсоткова частка складає $(6,0 \pm 0,7) \%$. Надалі виявлено досить швидке зростання ії частки до $(10,5 \pm 1,6) \%$ на 21 добу та $(17,0 \pm 1,1) \%$ - на 30 добу. В приблизно таких же відсотках вона спостерігається і у віддаленому та завершальному термінах дослідження - $(16,3 \pm 2,6) \%$ на 90 добу та $(13,3 \pm 2,5) \%$ - на 180 добу.

Зріла пластинчаста кісткова тканина спостергіається в регенератах тварин другої дослідної групи у вже значних кількостях на 21 добу з відсотком $(5,0 \pm 0,9) \%$. На 30 добу її частка зростає втричі - до $(14,0 \pm 0,7) \%$. Половину усього кісткового регенерату вона складає на 90 добу $(51,7 \pm 3,1) \%$, а на завершення спостереження практично відповідає фрізіологічним показникам та становить $(70,0 \pm 2,6) \%$.

Саме біодеградація матеріалу $є$ одним із вирішальних чинників остеокондуктивних властивостей композитних біорезорбуючих остеоімплантів і тому саме на оцінці відмінностей у швидкості біодеградації і було створено графрічне зображення (рис. 1), яке наочно характеризувало вищезгадані процеси.

Отримані дані дозволили впевнено зробити висновок, що біодеградація остеоімпланта з більшим вмістом гідроксиапатиту є повільнішою, а його вміст у ділянці імплантації залишається все ще значним навіть через 180 діб. Зменшення частки гідроксиапатиту сприяє більш швидшому розсмоктуванню кісткового замінника.

Для підтвердження есрективності застосування біорезорбуючої композиції було проведено погруповий порівняльний аналіз макропрепаратів (відпрепарованих нижніх щелеп, зафріксованих у формаліновому розчині) у завершальному терміні дослідження (180 доба).

У тварин контрольної групи ділянка дефекту чітко візуалізувався: можна було виділити краї десректу, які мали

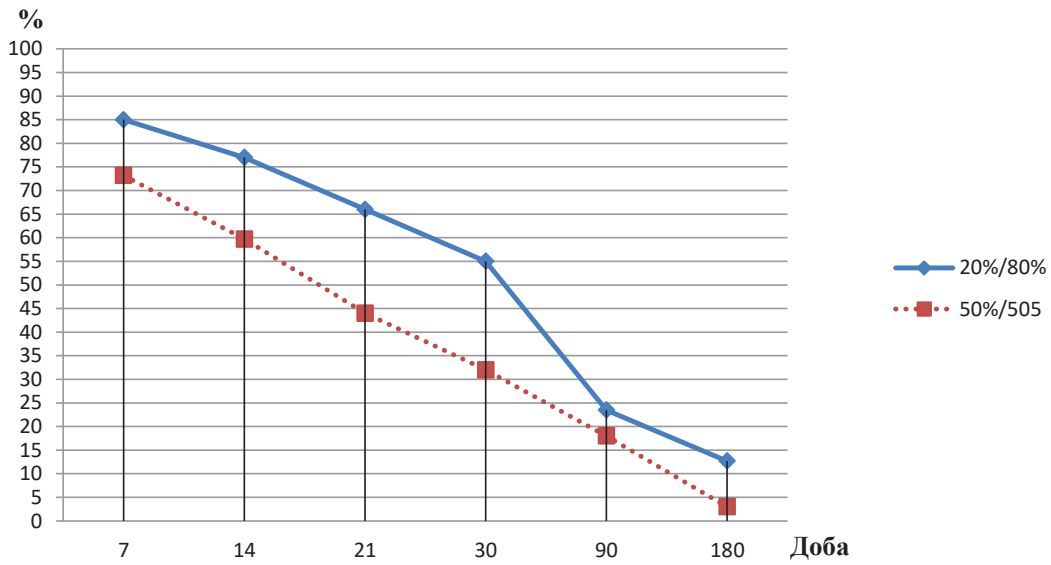

Рис. 1. Відсоткові показники вмісту остеоімпланта різних складів у регенераті дефектів нижньої щелепи піддослідних тварин. 
округлу фрорму на всьому протязі, а його вміст представлений немінералізованою, щільною тканиною, яка амортизувала при натисканні (рис. 2).

У тварин першої дослідної групи уся площина виповнена щільною тканиною, яка макроскопічно відрізняється від оточуючої кольором та щільністю. Репаративне кісткоутворення відбувалося із значною гіпертрофією, а сам регенерат у вигляді півсфери виступає над здоровою неушкодженою кісткою, його поверхня була гладкою. Місцями у ньому можна виявити нерезорбовані залишки кісткового імплантата (рис. 3).

При огляді макропрепаратів тварин другої дослідної групи на 180 добу краї дефекту виявлялися лише фррагментарно, на більшості своєї протяжності його вміст зливався $з$ неушкодженою тканиною за кольором. Його поверхня була дрібногорбистою. Також ділянка десекту виділялася за стоншенням кістки, яке найбільше було у центральній ділянці. Тобто можна констатувати, що процеси регенерації, на відміну від другої дослідної групи, проходили з ознаками гіпотрофії.

ВИСновкИ Аналізуючи отримані дані макроскопічного обстеженя, можна констатувати, що вони повністю корелюють 3 отриманими результатами морфометричного дослідження.

Значні за своїм об'ємом дефекти загоюються шляхом поступового заповнення незрілою, слабомінералізованою тканиною із явищами на 180 добу остеосклерозу по краях десректу, що свідчить про фрормування навколо дефекту компактної пластинки.

Заповнення десекту матеріалом із значною кількістю синтетичного гідроксиапатиту сповільнює процеси кінцевого фрормування зрілого вторинного кісткового рубця, але сприяє повному відновленню анатомічної фрорми втраченої ділянки. Завдяки такому складу біоімплантата можна досягнути ефекту гіперкорекції та нарощування кісткової маси, що дуже часто необхідно у клінічній практиці як засобу підготовки альвеолярного відростка щелеп до протетичного лікування.

Застосування імплантата 3 пропорційним вмістом полілактиду та синтетичного гідроксиапатиту у зв'язку із його швидшою біодеградацією структурує колагенові волокна у регенераті на ранніх термінах загоєння, оптимізує формування органічного матриксу кістки та сприяє швидшій його мінералізації. Проте незважаючи на повне виповнення десректу зрілою кісткою, спостерігаються ознаки неповного відновлення анатомічної форми втраченої ділянки кістки та формування залишкового дефекту. Зважаючи на сказане, такий склад біоостеоімплантата раціонально використовувати при незначних за об'ємом десектах, або у випадках, коли відновлення анатомічної форми $€$ не принциповим.

Перспективи подальших досліджень Все вищевикладене дозволяє зробити висновок про перспективність використання вказаних кісткових замінників у клінічній практиці, що дозволить значно розширити можливості

\section{СПИСОК ЛІТЕРАТУРИ}

1. Alfaro F. H. Bone grafting in oral implantology / F. H. Alfaro // Quintessence Pub. - 2006. - P. 27-83; 85-106.

2. Kfir E. Minimally invasive guided bone regeneration / E. Kfir, V. Kfir, E. Kaluski // J. Oral Implantol. - 2007. -Vol. 33 (4). - P. 205-210.

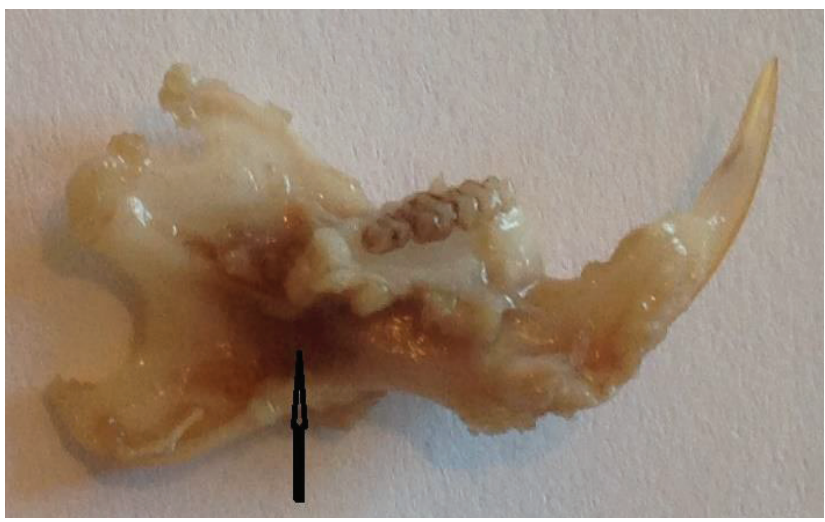

Рис. 2. Фотографрія макропрепарату тварин контрольної групи на 180 добу (стрілкою вказана ділянка дефекту)

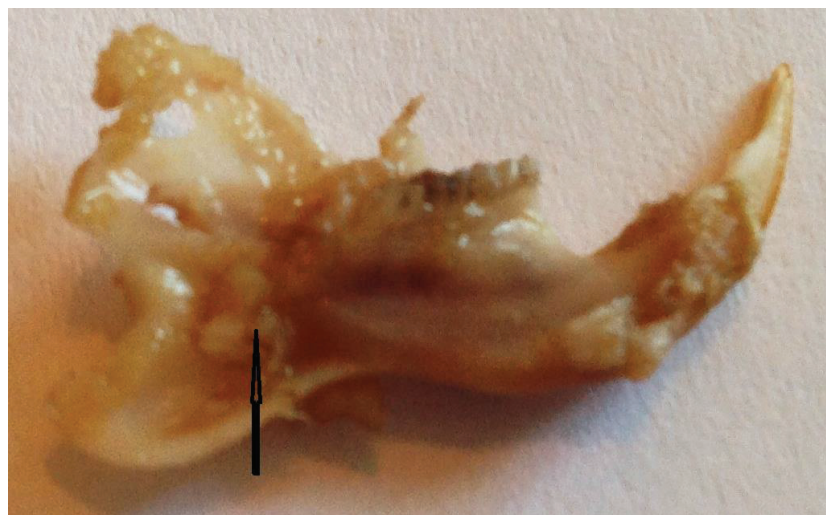

Рис. 3. Фотографрія макропрепарату тварин першої дослідної групи на 180 добу (стрілкою вказана ділянка десекту).

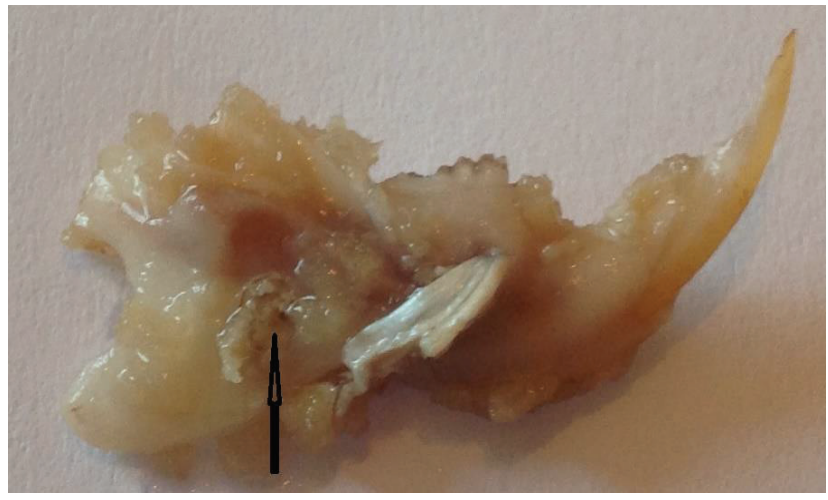

Рис. 4. Фотограсрія макропрепарату тварин другої дослідної групи на 180 добу (стрілкою вказана ділянка дефекту).

сучасної реконструктивної і відновлювальної щелепнолицевої хірургії, більш повноцінно вирішувати питання реабілітації пацієнтів до наступного протетичного лікування.

3. The biology of bone grafting / S. N. Khan, F. P. Cammisa, H. S. Sandhu [et al.] // J. Am. Acad. Orthop. Surg. - 2005. - No. 13 (1). - P. 77-86.

4. Smieszec-Wilczewska J. Comparison of postoperation bone defects of alveolar processes of maxilla and mandible with the use 
of Bio-Gen and Bio-oss / J. Smieszec-Wilczewska, R. Koszowski, J. Pajak // J. Clin. Exp. Dent. - 2010. - Vol. 2(2). - P. 60-66.

5. Современное состояние вопроса о костнопластических материалах стимулирующих остеогенез / И. П. Ардашев, С. В. Черницов, И. Ю. Веретельникова [и др.] // Вестник новых медицинских технологий. - 2011. - Т. XVIII, № 4. - С. 161-165.

6. Базикян Э. А. Восстановление костной ткани методом пересадки костных блоков (часть 2) / Э. А. Базикян, Б. С. Смбатян // Клиническая стоматология. - 2009. - № 1. - С. 44-54.

7. Германов В. Г. Костно-пластическая хирургия: от костного трансплантата до современных биокомпозиционных материалов / В. Г. Германов, Г. М. Ковалерский, З. А. Черкашена // Медицинская помощь. - 2006. - № 4. - С. 16-19.

8. Гизатулин Р. А. Средства для оптимизации остеогенеза в стоматологи: область применения, актуальность проблемы и перспективы разработок и внедрения новых препаратов / Р. А. Гизатулин. - М., 2007. - 152 с.

9. Гурин А. Н. Сравнительная оценка влияния различных остеопластических материалов на основе фоссрата кальция на заживление костных десектов : автореф. дисс. на соискание уч. степени канд. мед. наук : спец. 14.00.21 "Стоматология" // А. Н. Гурин. - М., 2009. - 26 с.
10. Eglin D. Degradable polymeric materials for osteosynthesis: tutorial / D. Eglin, M. Alini // European Cells and Materials. - 2008. - Vol. 16. - P. 80-91.

11. Наповнені гідроксиапатитом композиційні полімерні матеріали для заміщення кісткової тканини / Н. Семенюк, О. Сірий, О. Галишин [та ін.] // Вісник Нац. ун-ту “Львівська політехніка", "Хімія", технологія речовин та їх застосування". - Львів, 2010. - № 667. - С. 452-455.

12. Семикозов О. В. Лабораторное исследование минералнаполненого композита полилактида, подвергнутого воздействию сверхкритического диоксида углерода для применения в челюстно-лицевой хирургии / О. В. Семикозов, Е. В. Мокренко, В. К. Попов // Стоматология для всех. - 2006. - № 4. - С. 29-31.

13. Лосев В. Ф. Применение пористого минералнаполненого полилактида с мезенхимальными стромальными клетками костного мозга для стимуляции остеогенеза : авторефр. дисс. на соискание уч. степени канд. мед. наук : спец. 14.00.21 "Стоматология" // В. Ф. Лосев. - М., 2009. - 25 с.

14. Макєєв В. Ф. Застосування полімерних остеопластичних матеріалів у стоматології / В. Ф. Макєєв, М. О. Черпак // Український стоматологічний альманах. - 2013. - № 1. - С. 116-119.

15. Автандилов Г. Г. Медицинская морфометрия : руководство / Г. Г. Автандилов. - М. : Медицина, 1990. - 382 с.

Отримано 20.07.17

\title{
THE FEATURES OF MORPHOLOGICAL CHANGES IN BONE TISSUE AFTER USING THE MATERIAL BASED ON
} HYDROXIAPATITE AND POLYLACTIDE

\begin{abstract}
Summary. Osteoregeneration in bone defects of jaws restorations is an important issue in modern dentistry. A large number of articles confirm that the ideal material does not exist yet and that is why its search is relevant.

The aim of the study - to learn the osteoregeneration processes by morphometric evaluation of micropreparations and conducting a comparative analysis of reparation in correlation with macroscopic data on 180 day of the experiment.

Materials and Methods. The experiment was conducted on white male rats weighing 180-200 g. Under general anesthesia animals created a through hole in the jaw area. In the control group, healing was performed only under blood convection, and in the experimental groups, the bone defect was replaced with a hydroxyapatite and polylactide based substance with different percentages of components (group 1 (80 \%: $20 \%$ ) and group 2 (50\%: $50 \%$ ) ) Morphometric evaluation was carried out with using an inserts of an eyepiecemicrometer with measuring grids for cytogystostereometric studies. At macroscopic examination, the overall view of the removed jaws and adjacent tissues was visually assessed.

Results and Discussion. In control groups the regeneration with non-mineralized tissue, similar to structure to the organic matrix of the bone was observed. Osteoimplantant with the correlation of polylactide and synthetic hydroxyapatitis 20/80 percentages promotes a smaller tissue destruction, structurally corrects organization of the organic bone matrix and its faster mineralization with the formation of a primary bone marrow for 30 days. At $180^{\text {th }}$ day, the processes of restructuring and transformation of the bone tissue are still quite intense. When applying the implant with the 50/50 percentages, regeneration has a more favorable course, as it was evidenced by the practical restoration of the bone structure for 180 days of observation, when the bulk of the regenerate $(70 \%)$ in the defect was represented by a mature lumbar bone. Data obtained in the evaluation of macro drugs of the lower jaws of animals correlated with the data morphometric study.

Conclusions. The filling of bone defects by the proposed osteo implants changes the course of regeneration. It was established that filling the defect with a resorbable composite reduces destructive processes and accelerates the formation of the primary and secondary bone mosaic. From this point of view, the composition with the same content of both its components was more effective.
\end{abstract}

Key words: bone defect; regeneration of bone tissue; hydroxyapatite; polylactide.

\section{ОСОБЕННОСТИ МОРФОЛОГИЧЕСКИХ ИЗМЕНЕНИЙ В КОСТНОЙ ТКАНИ ПРИ ПРИМЕНЕНИИ МАТЕРИАЛА НА ОСНОВЕ ГИДРОКСИАПАТИТА И ПОЛИЛАКТИДА}

Резюме. Остеорегенерация при восстановлении костных дефректов челюстей является важным вопросом современной стоматологии. Несмотря на многочисленные исследования, идеального материала все еще не существует, поэтому его поиск является актуальным. 
Цель исследования - изучить процессы остеорегенерации путем моророметрического оценивания микропрепаратов и проведения сравнительного анализа репарации в корреляции с макроскопическими данным на 180 сутки эксперимента.

Материалы и методы. Эксперимент проведен на белых крысах-самцах массой 180-200 г. Под общим обезболиванием животным создавали сквозное отверстие в области челюсти. В контрольной группе заживление происходило только под кровяным свертком, а в опытных группах костный дефект восстанавливался материалом на основе гидроксиаппатита и полилактида с различным процентным содержанием компонентов (первая группа (80 \%/20 \%) и вторая группа (50 \%/50 \%)). Морфометрическая оценка осуществлялась с помощью вставок окуляра-микрометра с измерительными сетками для цитогистостереометричных исследований. При макроскопическом обследовании визуально оценивали общий вид изъятых челюстей и окружающих дефект тканей.

Результаты исследований и их обсуждение. Значительные по своему объему десекты нижней челюсти имеют тенденцию к искаженной и заместительной регенерации с восстановлением практически всего объема неминерализированной тканью, близкой по своему строению к органическому матриксу кости. Остеоимплантат с соотношением полилактида и синтетического гипроксиапатита 20/80 способствует меньшей деструкции тканей, структурно правильной организации органического матрикса кости и быстрой его минерализации с формированием первичной костной мозоли на 30 сутки. На 180 сутки процессы перестройки и трансформации рубца в зрелую костную ткань происходят еще достаточно интенсивно. При применении имплантата в составляющей пропорции 50/50 регенерация имеет более благоприятное течение, о чем свидетельствует практическое восстановление структуры кости на 180 сутки наблюдения, когда основную часть регенерата (70 \%) в десекте представлено зрелой пластинчатой костью. Данные, полученные при оценке макропрепаратов нижних челюстей животных, коррелировали с данными морфометрического исследования.

Выводы. Заполнение костных десектов предложенными остеоимплантатамы меняет ход регенерации. Установлено, что восстановление дефекта резорбирующим композитом уменьшает деструктивные процессы и ускоряет фрормирование первичной и вторичной костной мозоли. В этом отношении более эффективной оказалась композиция с одинаковым содержанием обеих ее составляющих.

Ключевые слова: костный дефект; регенерация костной ткани; гидроксиапатит; полилактид. 